Grażyna NOWICKA

IEiB UKSW Warszawa

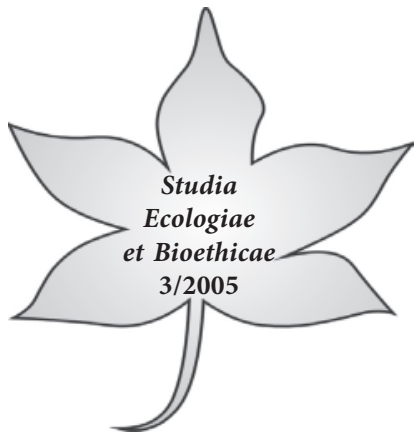

\title{
Komórki macierzyste - możliwość ich wykorzystania do regeneracji tkanek
}

Rozwój nauk biologicznych przyczynia się do lepszego poznania procesów związanych z rozwojem i działaniem różnych organizmów, w tym organizmu człowieka, a jednym $\mathrm{z}$ efektów postępu naukowego w tym zakresie jest opracowywanie coraz doskonalszych metod diagnozowania i leczenia chorób.

Ostatnio szczególne zainteresowanie wśród naukowców i lekarzy wzbudzają komórki macierzyste. Celem badań komórek macierzystych jest poznanie mechanizmów kierujących procesami tworzenia i rozwoju komórek, tkanek i narządów, a także opracowanie metod ich wykorzystania do regeneracji uszkodzonych tkanek i narządów np. do regeneracji mięśnia sercowego uszkodzonego w czasie zawału lub komórek trzustki, które utraciły zdolność produkcji insuliny (co leży u podstaw rozwoju cukrzycy typu I), komórek nerwowych, które utraciły zdolność syntezy dopaminy (co wiąże się z rozwojem choroby Parkinsona)( (1-7).

\section{Komórki macierzyste - cechy charakterystyczne}

Komórki macierzyste (ang. stem cells) są populacją komórek, które stanowią źródło (inaczej: macierz) prekursorów komórek różnych typów. Dlatego nazywamy je komórkami niezróżnicowanymi. W określonych warunkach fizjologicznych lub eksperymentalnych, tzn. w przypadku obecności w środowisku określonych substancji i sygnałów, zaczynają się one różnicować i tworzyć komórki określonego typu i tkanki.

Komórki macierzyste znalezione zostały w zarodku (tzw. zarodkowe komórki macierzyste) a także we krwi pępowiny (tzw. płodowe komórki macierzyste) oraz w szpiku kostnym dorosłego człowieka (tzw. somatyczne komórki macierzyste lub komórki macierzyste pochodzące od dorosłych). Komórki macierzyste obecne są także w innych tkankach osób dorosłych np. skórze, naczyniach krwionośnych, mięśniach. Trudno jednak odpowiedzieć na pytanie: czy powstały one w tych tkankach czy wywodzą się z komórek macierzystych szpiku. 


\section{Zarodkowe komórki macierzyste}

Najbardziej pierwotnymi i najbardziej wszechstronnymi w świetle aktualnej wiedzy są zarodkowe komórki macierzyste. Komórki te obecne są we wczesnej fazie rozwoju zarodka, w tej jego części, z której rozwijają się trzy listki zarodkowe a z nich wszystkie komórki organizmu:

- listek zewnętrzny (ektoderma) z którego powstają m.in. neurony, komórki skóry;

- listek środkowy (mezoderma) z którego rozwijają się m.in. komórki szpiku kostnego, mięśnie gładkie i szkieletowe oraz mięsień sercowy. a także naczynia krwionośne;

- listek wewnętrzny (endoderma) będący źródłem m.in. komórek trzustki, wątroby, tarczycy i płuc.

Ze względu na zdolność przekształcania się w komórki różnych typów, zarodkowe komórki macierzyste określa się mianem totiopotencjalnych lub komórek o dużej plastyczności (elastyczności). Plastyczność komórek maleje wraz ze wzrostem stopnia ich zróżnicowania.

Informacje dotyczące zarodkowych komórek macierzystych pochodzą przede wszystkim z badań nad komórkami zwierzęcymi. Prace z komórkami ludzkimi prowadzone są bowiem $\mathrm{w}$ ograniczonym zakresie, gdyż wiąże się to $\mathrm{z}$ wieloma problemami etycznymi.

Zarodkowe komórki macierzyste ze względu na swą wielką plastyczność mogą być wykorzystywane do regeneracji różnych tkanek. Jednak uzyskanie z nich komórek określonego typu wymaga poznania sygnałów nakazujących im różnicowanie się w określonym kierunku, tworzenie połączeń umożliwiających przekazywanie i odbieranie sygnałów od innych komórek organizmu, tak aby zregenerowana tkanka stała się tkanką organizmu: spełniała przypisaną jej rolę, współdziałała $\mathrm{z}$ innymi tkankami i zapewniała prawidłowy przebieg określonych procesów metabolicznych. Nie ulega wątpliwości, iż stworzenie tak skomplikowanego układu w warunkach in vitro jest sprawą niezwykle złożoną. Dlatego zainteresowano się podawaniem komórek macierzystych bezpośrednio do uszkodzonych tkanek (narządów), aby umożliwić ich szybkie wykorzystanie przez te tkanki do samonaprawy. Dotychczasowe badania pokazują jednak, że ze względu na swą wielką elastyczność (totiopotencjalność) zarodkowe komórki macierzyste mogą łatwo różnicować się w niepożądanych kierunkach, czego wyrazem jest tworzenie potworniaków. Aby zmniejszyć prawdopodobieństwo nowotworzenia lub innego niepożądanego kierunku ich przekształceń, próbuje się ukierunkowywać rozwój tych komórek przed ich podaniem do uszkodzonych tkanek lub jednocześnie z komórkami podawać odpowiednie czynniki silnie wpływające na ich przemiany. Wyniki licznych badań pokazują, iż poznanie czynników ukierunkowujących rozwój komórek macierzystych umożliwi ich wykorzystanie do 
hodowli określonych tkanek. Opisano m.in. szereg czynników związanych z procesem rozwoju komórek mięśnia sercowego (8-14). W badaniach na zwierzętach wykazano m.in., że wszczepione do serca zwierząt wyhodowane in vitro komórki mięśnia sercowego, powoduje naprawę jego struktury in vivo.

Przeszczep komórek macierzystych lub uzyskanych z nich komórek pochodnych, odpowiednio zróżnicowanych, podobnie jak przeszczep organów od obcego dawcy może zostać odrzucony przez organizm biorcy, gdyż rozpoznawany jest przez jego układ immunologiczny jako intruz. Dlatego przy przeszczepach komórek, tak jak przy przeszczepach organów, konieczne jest stosowanie terapii immunosopesyjnej. Do odrzucenia przeszczepu nie dojdzie, jeśli genotyp wszczepionych komórek będzie identyczny z genotypem biorcy. Oznacza to, iż komórki te muszą pochodzić z organizmu biorcy lub zostać wyhodowane drogą klonowania $\mathrm{z}$ zastosowaniem transfenu jąder $\mathrm{z}$ komórki somatycznej biorcy. Badania pokazały, że uzyskane metodą klonowania zarodkowe komórki macierzyste myszy wszczepione do uszkodzonego przez zawał serca tego zwierzęcia powodowały rozwój zdrowej tkanki mięśniowej, która zregenerowała ok. 40\% blizny zawałowej.

Naukowcy koreańscy z Uniwersytetu w Seulu, stosując metodę transferu jąder komórek somatycznych, wyhodowali linię ludzkich zarodkowych komórek macierzystych. Ich badania jeszcze raz pokazały, iż prace w tym zakresie wiążą się z bardzo wieloma problemami natury poznawczej, obejmującej zarówno konieczność pokonania wielu problemów technicznych jak i poznania mechanizmu rozwoju i różnicowania komórek, tworzenia struktur tkankowych itp. Towarzyszy im również wiele wątpliwości natury etycznej dotyczacych m.in. zakresu i zasad prowadzenia prac nad klonowaniem i hodowla in vitro zarodkowych komórek macierzystych i ich wykorzystaniem w celach terapeutycznych. Analizując dane literaturowe można stwierdzić, że aktualnie prace dotyczące ludzkich komórek zarodkowych koncentrują się na komórkach tworzonych in vitro i nie wykorzystują układów powstających in vivo. Jest to bardzo ważny element, wpływający na opracowywanie procedur technologicznych, a także na dyskusje dotyczące problemów etycznych związanych z prowadzeniem tych prac. Oznacza, iż zarodek powstaje $\mathrm{w}$ wyniku łączenia komórek rozrodczych in vitro lub transferu jąder komórek somatycznych. Planując prace i uzyskując pozwolenie od dawców na użycie ich komórek w tego typu eksperymentach z góry należy określić zakres możliwości wykorzystania tych komórek, zakres zarówno prowadzonych badań in vitro jak i zakres możliwość wykorzystania tak powstałych komórek w badaniach in vivo. Trudno jednak ocenić, czy i w jakim stopniu zarówno sposób uzyskiwania komórek macierzystych, jak i wyznaczane przez eksperymentatorów cele i zakresy prowadzonych badań, będą wpływać na kierunek dyskusji dotyczacej dopuszczalności tego typu eksperymentów. Prowadzenie szerokiej, spokojnej i rzeczowej dyskusji na ten temat, uwzględniającej różne racje i poglądy, jest 
sprawą niezwykle ważną. Bez niej niemożliwym stanie się ustalenie wspólnego, powszechnie akceptowanego i obowiązującego stanowiska w tej sprawie i dalszy rozwój tej dziedziny wiedzy.

\section{Komórki macierzyste pochodzące od dorosłych organizmów}

W badaniach nad wykorzystaniem komórek macierzystych do regeneracji tkanek i narządów uwagę koncentruje się przede wszystkim na pracach dotyczących komórek pochodzących od dorosłych organizmów. Uzyskiwanie i hodowla tych komórek nie wzbudzają istotnych wątpliwości natury etycznej, co umożliwia prowadzenie szeroko zakrojonych prac eksperymentalnych w układach in vitro i in vivo, nie tylko u zwierząt ale także u ludzi.

Dotychczas najwięcej prac dotyczy komórek macierzystych szpiku kostnego. Szpik zawiera krwiotwórcze komórki macierzyste, z których rozwijają się wszystkie typy komórek krwi. Komórki podścieliska są prekursorami tzw. mezenchymalnych komórek macierzystych, wielopotencjalnych komórek progenitorowych a także komórek tkanki kostnej i komórek tkanki tłuszczowej $(3,15)$.

Uważa się, iż ciągła i niezwykle szybka odbudowa komórek układu krwiotwórczego związana jest właśnie z obecnością w szpiku populacji krwiotwórczych komórek macierzystych. Prace nad izolacją tych komórek pokazały, że ich ilość w szpiku jest niewielka: jedynie jedną taką komórkę można znaleźć w populacji ok. 10000 komórek szpiku (16). Obecne w szpiku mezenchymalne komórki macierzyste mogą być źródłem różnych komórek m.in. komórek mięśnia sercowego $(17,18)$. Znalezione w szpiku mezodermalne komórki progenitorowe są komórkami o mniejszej niż pierwotne komórki macierzyste zdolności do różnicowania się i stanowią prekursory komórek określonych tkanek. Rodzajem komórek progenitorowych są także mioblasty, czyli prekursory komórek mięśniowych. Mioblasty mogą być pobierane z mięśni szkieletowych pacjenta i wszczepione do mięśnia sercowego. Dotychczasowe próby kliniczne dokumentują poprawę funkcji mięśnia sercowego u pacjentów poddanych tego typu zabiegom (4,19-22). Prowadzone są również prace nad modyfikacjami genetycznymi mioblastów. Komórki te wzbogacane są w geny kontrolujące syntezę różnych białek, np. czynników wzrostu, w celu zapewnienia jak najlepszych warunków wzrostu i działania przeszczepów komórkowych $(4,23)$.

Bardzo ważnym elementem procedury transplantacji komórek macierzystych jest opracowanie i stosowanie odpowiednich technik podawania (wszczepienia) tych komórek. Techniki te muszą zapewnić dotarcie komórek do uszkodzonych tkanek i ograniczyć możliwość ich umiejscowienia się w niepożądanych miejscach i wywoływania niepożądanych efektów.

Stopień inwazyjności i możliwość powtarzania transplantacji to czynniki istotne determinujące zakres wykonywania tego typu zabiegów. W opisywanych 
badaniach transplantacja komórek macierzystych towarzyszyła planowanym zabiegom kardiochirurgicznym (17). Implantacji dokonywano także domięśniowo stosując cewniki wprowadzone przezskórnie $(25,26)$. Ponadto stosowano techniki podawania dowieńcowego (26),a także podawanie dożylne (27).

Dotychczasowe badania pokazują, iż wykorzystanie komórek macierzystych do regeneracji uszkodzonych tkanek i narządów jest technicznie możliwe i może znaleźć zastosowanie w praktyce klinicznej. Nasza wiedza na temat tych komórek, metod ich identyfikacji, izolacji, hodowli, transplantacji, zasiedlenia i rozwoju w określonych tkankach jest jednak ograniczona. Istnieje cały szereg problemów, których wyjaśnienie jest niezbędne w celu określenia rzeczywistych możliwości i korzyści, a także ewentualnych działań niepożądanych stosowania tego typu procedur w praktyce. Rozwiązanie tych problemów wymaga prowadzenia szeroko zakrojonych prac badawczych w układach in vitro i in vivo.

\section{Piśmiennictwo}

1. Solter D., Gerhart J. Putting stem cells to work. Science 1999,283:1468.

2. Rosenthal N. High hopes for the heart. N.Engl.J.Med. 2002, 344:1784.

3. OrLic D. et al. Stem cells for myocardial regeneration. Circ.Res. 2002, 92:1092.

4. Kurpisz M. i inni. Transplantacje komórek w leczeniu chorób serca. Kard. Pol. 2003, 59, Supl. II:26.

5. ZALEwSKi J. i inni. Komórki macierzyste pochodzące od dorosłychw regeneracji uszkodzonego zawałem miokardium. Kard.Pol. 2003, 59, Supl. II:41

6. Kuehle I. et al. The therapeutic potential of stem cells from adults. BMJ 2002, 325:372.

7. Rosenthal N. Prometheus's vulture and the stem cell promise. N.Engl. J.Med.2003, 349:267.

8. Slager H.G. et al. Transforming growth factor beta in the early mouse embryo: implications for the regulation of muscle formation and implantation. Dev.Genet.1993, 14:212.

9. SRivastava D. et al. A genetic blueprint for cardiac development. Nature 2000, 407:221.

10. Maltsev et al. Cardiomyocytes differentiated in vitro from embryonic stem cells developmentally express cardiac specific genes and ionic currents. Cir. Res.1994, 75:233.

11. Musaro et al. Stem cell mediated muscle regeneration is enhanced by local isoform of insulin like growth factor 1. Proc.Nat.Acad.Sci.USA 2004, 101:1206 
12. Youn B.S. et al. Chemokines, chemokine receptors and hematopoiesis. Immunl.Rev. 2000, 177:150.

13. Kottmann A.H. et al. Function of the chemokine receptor CXCR4 in haematopoiesis and in cerebrall development. Nature 1998, 393:595.

14. SChuldiner M. et al. Effects of eight growth factors on differentiation of cells derived from human embryonic stem cells. Proc.nat.Acad.Sci.USA 2000, 97:11307.

15. JiAnG Y. et al. Pluripotency of mesenchymal stem cells derived from adult marrow. Nature 2002, 418:41.

16. HARrison D.E. et al. Number and continuous proliferative pattern of transplanted primitive immunohematopoietic stem cells. Proc.Nat.Acad.Sci.USA 1988, 85:822.

17. Sтамм C. et al. Autologous bone-marrow stem cell transplantation for myocardial regeneration. Lancet 2003, 361:45.

18. Murayama T. et al. Bone marrow derived endothelial progenitor cells for vascular regeneration. Cur.Opin.Mol.Ther.2002, 4:395.

19. TAYLOR D.A. et al. Regenerating functional myocardium: improved performance after skeletal myoblast transplantation. Nat.Med.1998, 4:929.

20. Menasche P. et al. The pioneering case of autologous myoblast transplantation in a human patients. Lancet 2001, 357:279.

21. Siminiak T. et al. Myoblast transplantation in the treatment of postinfarction myocardial contractility impairment: a case report. Kard.Pol.2002, 56:131.

22. Menasche P. et al. Autologous skeletal myoblast transplantation for severe postinfarction left venticular dysfunction. J.Am.Coll.Cardiol.2003, 41:1078.

23. SuzUKi K. et al. Cell transplantation for the treatment of acute myocardial infarction using vascular endothelial growth factor expressing skeletal myoblasts. Circulation 2001, 104:207.

24. Strauer B.E. et al. Myocardial regeneration after intracoronary transplantation of human autologous stem cells following acute myocardial infarction. Dtsch.Med.Wochenschr.2001, 126:932.

25. Fuchs S. et al. Catheter-based autologous bone marrow myocardial injection in no-option patients with advanced coronary artery disease: a feasibility and safety study. Circulation 2002, 106, Suppl.II: 656.

26. Strauer B.E. et al. Repair of infarcted myocardium by autologous intracoronary mononuclear bone marrow cell transplantation in humans. Circulation 2002, 106:1913.

27. Asahara T. et al. Bone marrow origin of endathelial progenitor cells responsible for potent vasculogenesis in physiological and pathological neorevascularization. Circ.Res.1999, 85:221. 


\title{
Stem cells and tissue regeneration
}

\begin{abstract}
Stem cells there are undifferentiated, primitive cells with ability to differentiate into specific kinds of cells. Stem cell research has a history of more than 20 years and has made an outstanding contribution to our understanding of haematopoiesis and embryology. Stem cells hold the promise of allowing researchers to grow specialized cells or tissue, which could be used for treatment of injured tissues.

Development of this area depends on the results of ethical debate over stem cell research, which is controversial, because the most powerful human stem cells there are embryonic stem cells.

Adult bone marrow has been found as an important source of adult stem cells. Adult stem cells have been used in animal and human studies for tissue regeneration. The utility of stem cell transplantation for the treatment of acute myocardial infarction to repair of injured myocardium has been shown.
\end{abstract}

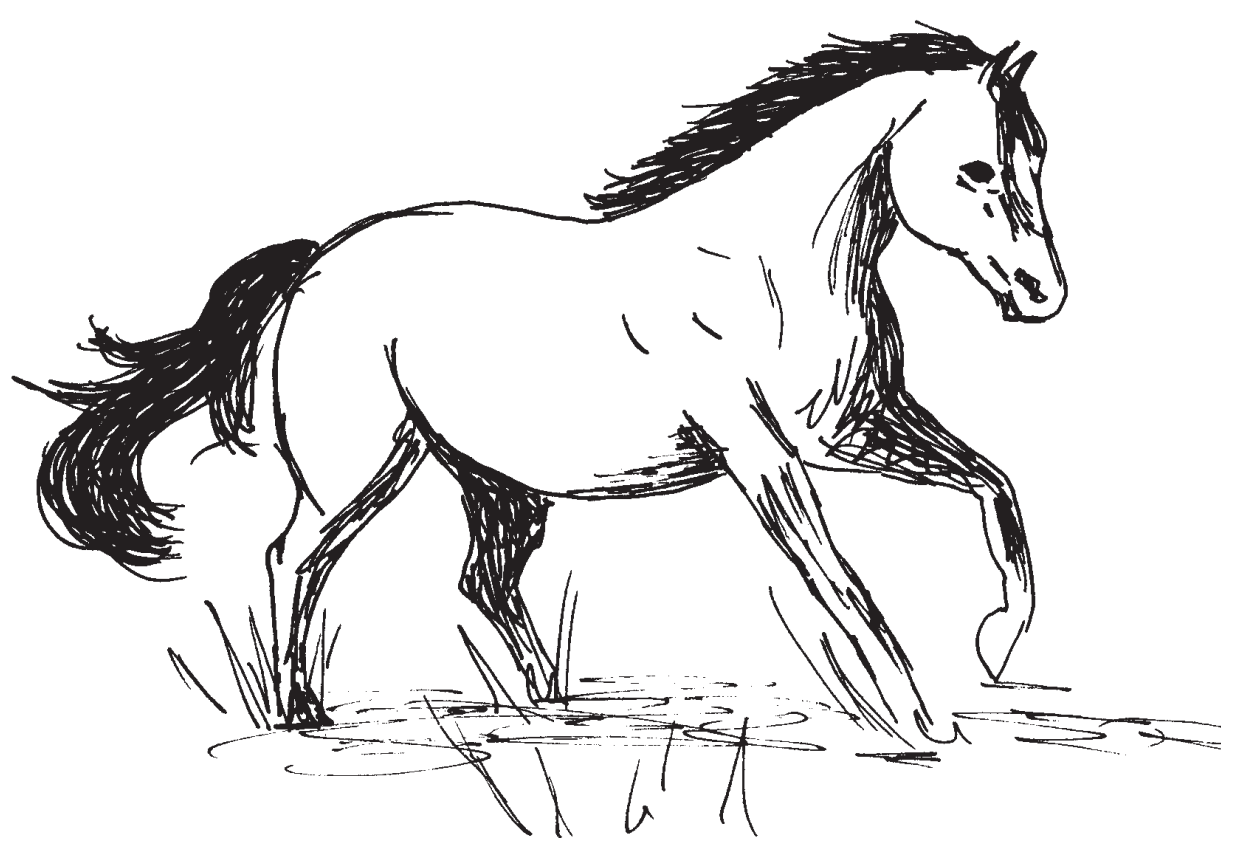

Rys. Marta Traczewska 